\title{
Can semiotics be used to drive paradigm changes in medical education?
}

\author{
John Tredinnick-Rowe \\ Faculty of Health and Human Sciences \\ University of Plymouth \\ Plymouth, United Kingdom \\ e-mail: john.tredinnick-rowe@plymouth.ac.uk
}

\begin{abstract}
This essay sets out to explain how educational semiotics as a discipline can be used to reform medical education and assessment. This is in response to an ongoing paradigm shift in medical education and assessment that seeks to integrate more qualitative, ethical and professional aspects of medicine into curricula, and develop ways to assess them. This paper suggests that a method to drive this paradigm change might be found in the Peircean idea of suprasubjectivity. This semiotic concept is rooted in the scholastic philosophy of John of St Thomas, but has been reintroduced to modern semiotics through the works of John Deely, Alin Olteanu and, most notably, Charles Sanders Peirce. I approach this task as both a medical educator and a semiotician. In this paper, I provide background information about medical education, paradigm shifts, and the concept of suprasubjectivity in relation to modern educational semiotic literature. I conclude by giving examples of what a suprasubjective approach to medical education and assessment might look like. I do this by drawing an equivalence between the notion of threshold concepts and suprasubjectivity, demonstrating the similarities between their positions. Fundamentally, medical education suffers from tensions of teaching trainee doctors the correct balance of biological science and situational ethics/ judgement. In the transcendence of mind-dependent and mind-independent being the scholastic philosophy of John of St Thomas may be exactly the solution medicine needs to overcome this dichotomy.
\end{abstract}

Keywords: medical education; medical semiotics; suprasubjectivity; curriculum reform; education; assessment 


\section{Introduction}

One of the fundaments of medicine is that the tuition and assessment of the medical profession is predicated on an ontological question, namely: what attributes and skills make for a good doctor (Huxham et al. 1989; O'Neil 2010; Conti 2005; Patel 2007). Before one can realistically determine what it is appropriate to teach, and which skills in particular need to be assessed, one has to ascribe utility and efficaciousness to those particular areas. A fundamental tension exists between producing students that can both account for the personal and emotional needs of patients, and act as vessels to be filled with biomedical knowledge. That is to say, there needs to be a synergy between the medical student as an applied scientist and a medical humanist (Hurwitz, Vass 2002) who considers the human and societal facets of the man or woman that stands before them, as well as the pathogen inside the patient.

In the search to define what qualities a good doctor should have, some have taken a patient-centred approach, by surveying the public (Bleakley 2014) who, as the recipients of care, have a central role in defining what makes a good doctor (Leahy et al. 2003; Fones et al. 1998). These factors themselves are, however, subject to change on some level, as the demographics and proclivities of patients can change within a society. Yet the role the doctor plays as a scientist is fixed in the sense that biological cause and effect will not change. As Leone (2017: 119) has noted, "given a cardiac arrest, you inject epinephrine, that's it"; the biological relationship between subject and object is determined at a chemical level. For this reason Sullivan (2003: 1595) associates subjective assessment in medicine with taking the patients' point of view into account: “The physicians' job description will be changed to focus on patients' lives rather than patients' bodies."

The fact that such a dichotomy exists places us in a predicament, where we must ensure the peaceful co-existence between the need to teach students what is objectively real; and the subjective environs and variable contexts within which we all exist. Such struggles have been in the minds of medical educators and assessors since the 1980s (Sloan et al. 1996; Ansell et al. 1979). More recently, it has been recognized as a consequence of this, that we are not producing doctors fit to deliver care in the 21st century (Institute of Medicine 2001; Frenk et al. 2010). As a medical educator I would echo Holmboe (2017) in this regard, that medical education should include,

[...] an emphasis on competencies beyond medical knowledge and basic clinical skills, such as systems thinking, quality improvement, interprofessional teamwork, and patient safety, while concomitantly attending to identity formation, wellness, and resilience. (Holmboe 2017: 2) 
Medical humanities can offer these skills, and semiotics contributes to what Peirce called the growth "in concrete reasonableness" (CP 1.590, 1903), and so towards a greater good (Peirce 1903).

Over the last several decades encouraging progress has been made in the pursuit to more evenly balance the teaching of each of these two positions to students in Western/Anglophone nations, primarily by the development of medical humanities subjects in medical schools (Gordon 2005), which has brought more patient-oriented values into the curriculum (McManus 1995). This is notable, given how medical education has traditionally (with intelligible reason) privileged biological fact over subjective context, leading academics and practitioners to favour one approach over the other and remain confined to their respective silos. Consequently, the teaching of contextual areas in medical practise, such as the ability of doctors to deal with ambiguity, is something that in recent years has fallen upon the medical humanities to deliver (Cox et al. 2003). I have illustrated this in Fig. 1.

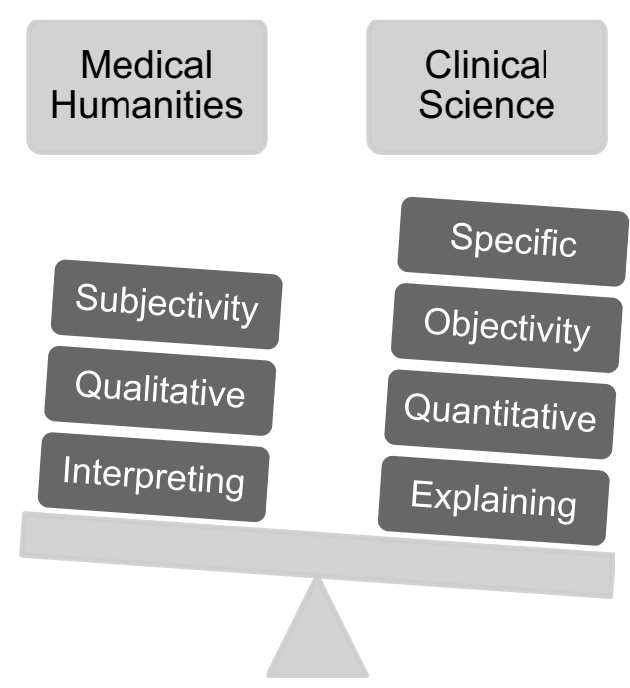

Figure 1. Differences between the philosophical and methodological foundations of medical humanities and clinical science.

In this paper, I outline some of the current issues associated with the paradigm shift that is occurring in medical education, and then propose how semiotics as a framework might help to account for or even overcome the tension in medicine 
associated with the dichotomy of objective and subjective forms of knowledge shown in Fig. 1. Primarily, medical education and assessment is in search of a disciplinary counterpart that can help account for the subjectivity of experience and specificity of individual processes that bio-statistical data cannot adequately address. In this paper, I am also concerned with how medical humanities (as a vehicle for understanding and dealing with ambiguity) might be more successfully integrated into core medical education curricula, as part of this paradigm shift.

This paper specifically engages with a semiotic theory related to the works of Charles Sanders Peirce, and why semiotics might be a useful frame to explore medical education and assessment. This concerns the idea of suprasubjectivity and how it might be a basis for re-framing medical education and assessment as a whole, to allow it to better integrate qualitative forms of assessment and humanistic practises into medicine. For further discussions about scholastic realism and the interplay between subjective and objective being see Sonesson 2018. This paper summarizes how semiotics as a meta-theory can drive paradigm shifts in medical education. The paper concludes that scholastic realism, which underpins various semiotic schools of thought (Deely, Cobley 2010), could become a well-balanced counterpoise for the scientific realism that underpins much of biology (French 2011).

\section{A shift in medical assessment?}

The epistemological shift in medical education to which this paper previously alluded is essentially about determining where the balance in Fig. 1 is set, between clinical and humanistic skills. The increasing need for patient-centred medicine, however, has involved overcoming a variety of challenges, primarily, turning policy and rhetoric into an implementable reality (Barry, Edgman-Levitan 2012). In medical education, tuition is still (understandably) weighted in favour of clinical subjects. Even though much progress has been made in introducing medical humanities to the curricula of undergraduate and postgraduate medical students, they are often treated as supplementary, decorative subjects (Belling 2010), rather than fundamental to the learning of the students.

However, perhaps surprisingly, one area where there does seem to be an appetite for change, and a will to incorporate subjectivity into practice, is within medical assessment and psychometrics ${ }^{1}$. Medical assessment as a subject is concerned with ensuring the exams medical students take are valid, and the knowledge, skills and attributes used to teach trainee doctors are accurately

1 This subject uses assessment results and statistics to determine the validity of examinations. 
assessed (Howley 2004). When we consider the fundamental question introduced at the beginning of the paper - what attributes and skills make good doctors? medical assessors are tasked with ensuring the exams students take accurately reflect the skills and qualities that $\mathrm{we}^{2}$ have deemed to be good. Consequently, the goal alignment between the medical curriculum and the assessment is critical in this area (Bloomfield et al. 2003). Once more, a fundamental tension arises that the qualitative values which make a good doctor: empathy, resilience etc., are reduced to test scores that can be statistically manipulated to establish grade boundaries. Such methods of assessment are epistemologically inconsistent and ill equipped to measure the constructs they are trying to assess.

More recently, though, there has been a move to incorporate qualitative assessment measures into the examinations of medical students to counteract this issue primarily exemplified by the introduction of narrative assessment in medicine; both in the USA (Ginsburg et al. 2015; Cook et al. 2015; Cook et al. 2016; Regehr et al. 2012; Hanson et al. 2013) and also in the Netherlands through programmatic assessment as championed by Schuwirth and Van Der Vleuten (2011). Important to note also is a paper by Cook et al. (2016) titled "When assessment data are words", which speaks directly to this issue.

There were signs of this shift in the keynote speeches of prominent assessment academics at the 2016 annual transaction of the European Board of Medical Assessors in Exeter, UK. Several interesting discourses emerged about the future of medicine and medical education. The conference addressed how the boundaries between medical assessment and other subjects might be crossed, and so gave insight to future developments of the field.

Some of the maxims that encapsulated this position were that medical assessors should learn to "embrace the subjective" and consider the transition from 'numbers' to 'numbers and words' forms of assessment, the latter being a move from purely psychometric assessment to the integration of qualitative measures of assessment, or considering how to append existing assessments with qualitative aspects. Particularly salient at the conference was Chris McManus's keynote talk "Failing to cross boundaries: Is remediation possible and how much extras training is needed?"3 which highlighted the difficulties posed by trying to assess cumulative and progressive attainment data, and produce a reliable estimate of how much

2 The key issue being here, who defines what a good doctor is? There are many answers including patients, the public, doctors themselves, medical regulators etc., many of which have conflicting interests.

3 McManus, Chris 2016. Failing to cross boundaries: Is remediation possible, and how much extra training is needed? Keynote talk given at the EBMA Annual Academic Conference Crossing Boundaries - Assessment in Medical Education, Exeter, United Kingdom, 14 October 2016. 
more education a remedial student requires before they can return to the status quo, i.e. re-join their classes.

The keynote speech had strong elements of dialectical reasoning as a methodology aiming at overcoming some of the epistemological limitations of psychometric assessment data, in the sense that when all the existing quantitative assessment data on the subject of remediation was collected, an answer to the question could still not be provided. This was a result of variability in the data, moreover the issue that quantification itself also contains philosophical limitations as to what it can possibly explain, especially when applied to inherently subjective assessments such as remediation. Such a position also highlights some of the existing limitations of assessing issues of professionalism like remediation through "big data". In sum, assessment data, even in large quantities, is too variable to provide accurate enough answers to a question about qualitative thresholds; or put more simply, what level of knowledge is required to make a good doctor?

This points towards the direction outlined. A shift would be required in the culture of assessment (of remediation in this case) to more meaningfully answer the question how much more education and remedial training do students require before they can return to practice. McManus' keynote, and others at the conference, recognized this.

It would seem that we are at the nascent stages of a move towards integrating qualitative assessment in medical education. As such, it is prudent to remember that medical education is by no means the first discipline to go through a rupture. In the next section, I explore how the works of Gaston Bachelard and his successors may be of use in learning how to negotiate this new and uncertain intellectual territory.

\section{A background to paradigm shifts}

Medical education and assessment are not the first disciplines to try to bear the cross of paradigm shifts. Given this, it is prudent to consider some potential sources of guidance from those scholars who have previously sought to solve the epistemological problems associated with crossing boundaries into different subject areas.

Approaches to the integration of such seemingly contradictory positions has a longer pedigree than one might expect: its genesis can be traced to French philosopher of science Gaston Bachelard (1884-1962) and his concept of epistemological rupture. Epistemological rupture or rupture épistémologique in its proper designation has had a profound impact on the development of both 
quantitative and qualitative approaches to science. In the moment that medical educators are posing existential questions about bridging the gap between subjective and objective knowledge, it is worthy of discussion. Bachelard's work proved to be influential over several modern thinkers including Althusser, Bourdieu, Foucault, but also notably Thomas Kuhn's notion of paradigm shifts. Whilst Bachelard was concerned with shifts in scientific perspective, some of his modern-day adherents, who took his work as a maître à penser, were also interested in critiquing and extolling the virtues of approaches that attempt syncretic integration such as mixed methods research, for example Bourdieu, who said his method was to:

[...] use Weber against Weber to go beyond Weber. In the same way one should follow Marx's advice when he said 'I am not a Marxist' and be an anti-Marxist Marxist. One may think with Weber or Durkheim, or both, against Marx to go beyond Marx and, sometimes, to do what Marx could have done, in his own logic. (Bourdieu 1988: 780)

It is worth noting that this approach is not novel but was devised by Bruno Bauer when he undertook to turn Hegel against himself in a method he called critical criticism (Marx, and Hegel 1956[1845]). It is this dialectic or "le mouvement d'enveloppement" (Bachelard 1940: 137), aiming at a continuous critique of a work through its own means, which helps to expose the paradoxical logic or limitations that can be found within a scheme or discipline. Much like the events that occurred in McManus's keynote talk.

Bourdieu went on to broaden Bachelard's (1968[1934]) conceptions of epistemological rupture to include the process by which one causes a rupture in both the narrow confines of scientific epistemology and also a break with sens practique or "common sense" (Mesny 2002). From this, it is evident that Bourdieu wished to achieve a social rupture as much as an epistemological one (Barnard 1991). This concept is key to understanding the integration of opposing scientific structures, a process that Bourdieu and Wacquant (1992) termed social praxeology. This resurfaces in his work The Science of Science and Reflexivity (Bourdieu 2004), the key point being that our medical education paradigm shift in part reflects a change in the wider cultural milieu of what is expected of doctors, and so it is not unfitting that this shift is designed to have social consequences as to how we teach and assess medicine. The implications of this would seem to be that we must try to foster a culture in medical education where the position of medical humanities is less marginal and more central to the purpose of educating doctors. 
Yet another French thinker to introduce to a discussion on paradigms is Michel Foucault, specifically the work in his publication The Order of Things (Les Mots et les Choses), where he introduced the concept of 'epistemes', which set the general conditions in knowledge for a certain period of time. Although Foucault never specifically used the term 'paradigm change' himself (Rabinow, Dreyfus 1982), both terms are still associated with a Gestalt Shift (DesAutels 1996). It is clear that epistemes make use of the notion of paradigm, although, their focus is more on how discourse becomes the methodology by which we historically articulate a paradigm. Hence, the key differentiation here is that the genealogical method of Foucault is much more historically-based (a-priori) than the sociological approach of Bourdieu or even Bachelard. That being said, the Foucauldian conception of paradigm change, with a greater historical emphasis may position us closer to Peirce (Cardoso 2016), with a greater emphasis on materiality than social structures (Keane 2003).

There is a meaningful and current debate in medical education about paradigm shifts (Pellegrino 1999; Gallagher et al. 2005; Scalese et al. 2008; Iobst et al. 2010; Holmboe et al. 2017). Holmboe in particular looks at the difficulties of shifting approaches to medical education in terms of undergraduate and postgraduate courses in Canada. In his paper "Competency-based medical education and the ghost of Kuhn: Reflections on the messy and meaningful work of transformation" he states:

Much of the tension and polarity revolve around how more effectively to prepare students and residents to work in and help change a complex health care system [...] Their primary purpose is to help facilitate implementation of an outcomesbased approach by creating shared mental models of the competencies, which in turn can help to improve curricula and assessment. (Holmboe 2017: 1)

This is also my aspiration for the paradigm shift occurring in the UK, but I would argue that medical humanities would lead to an increasing focus on process-based assessment rather than outcomes. Holmboe (2017: 2) does, however, highlight that regardless of the direction we wish to take, "paradigm shifts are messy and threatening, both for those wanting to remain with the older paradigm and those pushing the newer paradigm" (Holmboe 2017: 2), as Kuhn also notes (Kuhn 1962). Bachelard's epistemological rupture helps us comprehend that scientific progress can and has been predicated on the position of integrating seemingly contradictory elements, rather than continuing in the prevailing direction in an appeal to common sense. Moreover, it is fundamentally connected to catering to the needs of society as they change. What we must warn against, however, is the issue Gwendie 
Camp highlights, where paradigm shift towards humanistic medical education and assessment becomes a semantic sleight of hand or "passing fad" (Camp 1996), rather than a lasting change.

\section{The spectrum of subjectivity in semiotics, can it help us find a solution?}

Up to now, I have introduced issues associated with education and assessment in medicine. The following section is concerned with connecting semiotics to education and making recommendations about how this area might offer solutions to the current impasse in medical education. As such, this paper aligns with Shank (1995: 1), who wished to "show how qualitative research in education and semiotics can be brought together for the benefit of each field". However, my focus in this paper specifically relates to medical education.

The use of semiotics to analyse educational practise has been applied in a variety of different areas, including mathematics (Morgan 2006), general science (Lemke 1987), biology (Jaipal 2010) and many more. The connection between the two subjects is not a new intervention in academic thought, but an approach based on an older academic landscape (Pikkarainen 2011). Here, one might particularly make reference to John Dewey as one of the early pragmatists to work in education (Olteanu 2015). In more recent years the study of semiotics or applications of semiotics to education has been termed 'Edusemiotics' (Semetsky 2014; Stables, Semetsky 2016). However, medicine as a subject for whatever reason has yet to feature heavily in relation to educational semiotics, with only a few papers connecting the two areas (Pauli et al. 2000a, 2000b, 2000c).

One may not see too many parallels between medicine and semiotics as disciplines; however, if one considers how they are structured, a basic comparison can be made. In a conversation between Kalevi Kull and Umberto Eco, Eco remarks:

It is not a science [semiotics] in the way physics is a science because it is not accumulative like science is. [...] So semiotics, I always say, is like medicine. [...] I think that semiotics is something like this - a confederation of disciplines, sometimes using different methods, even though I am always ready to criticize one method and in this sense, it has no limits. (Kull 2017: 200)

One can see that structurally as a discipline (if indeed it is such), both medicine and semiotics contain a variety of heterogeneous, but linked specialties and areas, which may use different methods. 
This brings me to the primary mechanism for why semiotics might be a useful frame to explore medical education and assessment ${ }^{4}$. An understanding of semiotics, particularly in the Peircean form, could help medical students to better deal with uncertainty in practice. This is because Peircean semiotics, through the conception of suprasubjectivity, has found a way to overcome the ontological distinction between mind-dependent and mind-independent being (Olteanu 2015). If students can be taught to inculcate this thought process, it would help to reduce mental barriers to compartmentalizing objective and subjective knowledge. My reasons for making this statement are given in the following section.

\section{Suprasubjectivity}

Possibly the first semiotician to talk about uncertainty and education was the pragmatist John Dewey (1859-1952). This position has drawn much attention (Biesta 1994, 2010; Biesta, Burbules 2003; Garrison 1994, 1997, 1998, 2003; Garrison, Shargel 1988; Wilshire 1993). The premise of Dewey's approach is that thinking itself is fundamentally uncertain and that the only real antidote to this is reflection (D’Agnese 2017). In Dewey's own words:

We do not approach any problem with a wholly naïve or virgin mind; we approach
it with certain acquired habitual modes of understanding, with a certain store
of previously evolved meanings, or at least of experiences from which meanings
may be educed. If the circumstances are such that a habitual response is called
directly into play, there is an immediate grasp of meaning. If the habit is checked,
and inhibited from easy application, a possible meaning for the facts in question
presents itself. (Dewey 1910: 106)

Through the lens of reflection our habitual repositories of knowledge, from which we can draw to solve issues, grow. These processes need to be continuously encultured in medical education, and reflected in how doctors are assessed. These ideas are well expressed by the following from D’Agnese: “[...] we should conceive of education not so much as the attempt to encompass and to master experience, but as the means to create new, unpredictable experience, thus putting forward our relationship with the environment" (D’Agnese 2017: 84).

4 I fully acknowledge that there are other semiotic approaches that lend themselves to this problem, such as explaining current issues in medical education in reference to the concept of umwelt. However, for brevity's sake the works and implications of Jakob von Uexküll's scholarship are not discussed in this paper. 
Here education is seen as a process of adaptation (see Olteanu 2016,2017) that might help the student overcome uncertainties and new issues, rather than a more linear and instrumental interpretation that would seek to train doctors to mimic pre-existing tasks performed in training once they graduate onto the hospital wards. This position is closer to viewing the central function of both education and assessment as engaging the student with the processes of learning rather than the attainment of particular grades, i.e. learning as process rather than a product (Lachman 1997), and assessment mechanisms that could capture this shift in the function of learning, or, as John Dewey related, an education that can be free "from routine and from caprice" (Dewey 1917: 63). Similarly, and more currently, Strand (2013: 801) termed this process a "pedagogy of surprise" and Campbell (2016:30) a "pedagogy of novelty".

A comprehension of the fundamental uncertainty of thought as expressed by Dewey and others helps to explain why medical humanities scholars have placed importance on the ideas of context within medicine. Naturally, then, if we are to help students engage with uncertainty in real world practice, they should be instructed in a manner that helps them understand and account for subjectivity. Perhaps the best approach to the reflective thought Dewey recommends is to ensure that education and assessment are informed by Peirce's concept of suprasubjectivity (Olteanu 2015).

The concept of suprasubjectivity was a means by which Charles Sanders Peirce attempted to resolve (and transcend) an on-going philosophical dispute between those who characterize existence as mind-dependent (ens rationis) and those who characterize it as mind-independent being (ens reale), i.e., between idealist and realist schools of thought. Such an approach tries to reconcile "scientific" (realist/ objective) knowledge with humanities subjects (idealist/subjective) interpretations of the world. For a much more in-depth debate around this issue see Deely 2000 and Deely, Semetsky 2017.

To unpack the concept of suprasubjectivity I will quote at length sections of text from Paul Bains' The Primacy of Semiosis, as the idea cannot easily be reduced to a simple explanation. Much as Bourdieu (1990: 52) identified, sometimes complex issues require in-depth explanation and should not be parsed, if the reader is to avoid a deformed understanding of the concept being explained.

From a suprasubjective position the concept of a sign is "neither strictly subjective, neither strictly objective" (Olteanu 2015: 24). We are here concerned instead with the ontology of relations within a system, for example: "[...] formal signs are posited to account for the function of 'ideas' or 'concepts' as being, not sense-perceptible, but rather factors which nevertheless bring into awareness something other than themselves, something suprasubjective" (Bains 2014: 50). 
In the idea of 'something other than ourselves', the 'supra-' in suprasubjectivity, is essential to understanding the nature of the concept, i.e. signs are constituted as relations, and not a mere agglomeration of differing parts (Cobley 2017). Bains (2014: 11) describes this in the following way:

This is an expanded conception of subjectivity that included not only words and images but all the 'machinations' that go to make up those words and images. We are semiotic, existential territories rather than brains in vats, and these territories or ecologies are not contained within our physical anatomy, nor are they known only as immanent representations. The question becomes this: Where does your cognition or subjectivity terminate if it is a suprasubjective process and not a stable substance? The "self" becomes a sign relation or interpretant rather than an unrelated ontological entity.

The text continues:

What is being constantly emphasized is a kind of semiotic ontology in which relations become crucial at every level of analysis and allow for the interweaving of corporeal and incorporeal factors. Relations are an intrinsic dimension of being, and every being becomes the active centre of a web of relations, with other beings. The relations are, however, in what they are as relations, suprasubjective. They are not reducible to the relative being that enters into or generates these relations. A dilemma of much thought is the difficulty of thinking beyond the One or the Many and entertaining the concept of a multiplicity of different things or beings that are nevertheless in mobile relationships - the concept of a place where sometimes with the greatest difficulty, new relationships can be constructed. (Bains 2014: 11-12)

This statement demonstrate a paucity in the concept of intersubjectivity (Deely 2009): i.e. what is properly subjective, is over and above us, not merely between things, namely, supra-subjective. Bains also describes the concept in relation to the works of João Poinsot (John of St Thomas), the 17th-century Portuguese Scholastic philosopher:

[...] objective being as a pattern of univocal ${ }^{5}$ relations, some of which may also at the same time be physical relations. In this sense, objective being is not representative. It is not a middle term that is known first then on the basis of which something else might be known. It is a pure 'non-mediating' relation - it does not get in the way. Thus, Poinsot seeks to retain a certain Thomistic realism, while at the same time, and perhaps in spite of himself, he opens the way for a semiotics in which concepts are formal signs that bring into awareness something other than

5 See Deleuze 1990. 
themselves - but these 'objects' need not have extramental, physical existence, or they may mix up physical and ideal being. (Bains 2014: 10)

To this statement I would also relay the words of John Deely (2014: 593): “[...] that what underlies the possibility of semiosis in the first place at any level is the irreducibility of relations to subjectivity (including intersubjectivity)". To open ourselves up to relational forms of experience, involves a movement beyond conceptualizing persons as being a middle term between a sign and its terminus. Drawing from Cobley (2017), a further illustration of this distinction is given by John Deely (2015: 20) in the following hypothetical scenario:

We are supposed to meet for dinner; you show up and I don't (or vice versa), and you are annoyed until you find out that I died on the way to the dinner. At my moment of death, at the moment I ceased to have a material subjectivity encounterable in space and time, the relation between us went from being intersubjective as well as suprasubjective to being only suprasubjective; yet under both sets of circumstances I (or you) as the objective terminus of the dinner engagement remained suprasubjective (if not intersubjective!) as a constant influencing the behavior of the one still living in whom the relation retained a subjective foundation as a cognitive state provenating the relation as suprasubjectively terminating at an "other".

To clarify the concept of suprasubjectivity further, I will give some concrete examples of where approaches to medical education have (unknowingly) utilized this approach. The purpose of introducing suprasubjectivity into medical education is to introduce a process by which medical students start to understand both their personal and professional practice as something other than themselves, in terms of the fact that they are connected within an ontology of relations (Jauernig 2010) to a multiplicity of things including their patients, tutors and a wider political/cultural and economic milieu. Specific examples of this milieu include technological advances in medicine, and increasing comorbidity in patients (Beddhu et al. 2000). In the language of Deleuze and Guattari, this is a student becoming aware that they exist within a wider "ethico-aesthetic paradigm" (Guattari 1995).

This is a process that cannot be taught explicitly, but can be actively encultured in students. That being said, we cannot force upon students a new and unpredictable experience and simply expect them to learn effectively from it, but we can in a Deweyan sense develop pedagogies that give the space and 'the means to create new, unpredictable experience' (D'Agnese 2017: 84), through which students can foster the skills of adaptation that are required in the real world of clinical practice. The question remains, in general terms, what might these new 
and unpredictable experiences be? More specifically in semiotic terms, what might suprasubjectivity in medical education and assessment look like?

\section{Threshold concepts}

Some answers may be found in the pioneering work around threshold concepts in medical education. In relation to education, a threshold concept:

[...] can be considered as akin to a portal, opening up a new and previously inaccessible way of thinking about something. It represents a transformed way of understanding, or interpreting, or viewing something without which the learner cannot progress. As a consequence of comprehending a threshold concept there may thus be a transformed internal view of subject matter, subject landscape, or even world view. (Meyer, Land 2003: 415)

Semiotically, what are here described as threshold concepts, are the processes by which a student cognitively begins to access suprasubjective sign relations, that allow a differing perception of self, and one's wider environment. The student undergoes an ontological shift in relation to their own being, but also potentially in relation to the external world as well, or as Bains (2014: 10) describes it: "The "self" becomes a sign relation or interpretant rather than an unrelated ontological entity."

What then might these shifts or threshold concepts look like? If they are in fact suprasubjective experiences, I suggest they can be either physical (extramental), nonphysical (intramental), or a mixture of both. In addition to this, when exploring threshold concepts with students at Peninsula Medical School, Collett, Neve, and Stephen (2017) discovered the following examples with their clinical students:

- No single or morally correct answer: you might not always be able to provide the right answer to a patient.

- Being a doctor is more than just treating the symptoms: you cannot as a student just be smart, you have to develop a relationship with the patient.

- It's about the patient: the needs of patient outweigh the needs of the student.

- Working with uncertainty: knowing what to do isn't always clear.

Building on Wearn, O'Callaghan, and Barrow (2016) it is also important to highlight a threshold concept discovered by Randall (2017):

- You can't save everybody. Some of your patients will die. 
This threshold is typically passed when a student experiences their first patient dying. This is a particularly salient example, as one of the key features of threshold concepts is that the effect on the student is deemed to be irreversible (Meyer, Land 2005, 2006), which one would expect when the student first experiences their inability to prevent death. Equally, the crossing of liminal thresholds is also known to be troublesome (Meyer, Land 2003; Perkins 2006). This is something Bains (2014: 11-12) also observed about suprasubjectivity when he stated:

A dilemma of much thought is the difficulty of thinking beyond the One or the Many and entertaining the concept of a multiplicity of different things or beings that are nevertheless in mobile relationships - the concept of a place where sometimes with the greatest difficulty, new relationships can be constructed.

Intriguingly, Baines used scholastic philosophy to draw the same conclusion that Meyer and Land (2003) did, via collecting and analysing primary data. To give an illustrative example of what passing through a suprasubjective/threshold process might be like, we can turn to Neve et al. (2016: 850), who detail the following scenario between a student (pseudonym Kate) and her clinical tutor:

Prior to threshold change:

You have been Kate's academic tutor since she started at medical school 18 months ago. One of your roles is to support her to develop her reflective writing, a requirement of the programme's professionalism module. Kate has been resistant to the idea of reflective practice and you are not hopeful about your meeting this afternoon. She says that she cannot see the point of reflection and that the task is just "a hoop to jump through".

After threshold change:

When Kate arrives today, things are different. "I've got it!" she says "I finally get reflection!" Sure enough, her latest piece is insightful and analytical-she has written about her feelings and assumptions, explored dilemmas and considered others' perspectives. You discuss what she has learnt about being a patient and the kind of doctor she hopes to become. She shows you an App that she has downloaded to record future reflections on her smartphone. After 18 months, her view of reflective practice has, it seems, been transformed; she has crossed a threshold and navigated a troublesome concept in learning.

This story contains introspection, a consideration of the other, and future aspirations of the student. It also points to the use of physical items (phone apps) as well as cognitive changes. These examples appear to reify the qualities and materials described by Bains that constitute the basis of suprasubjectivity, which seems to support the idea of suprasubjectivity as a transcendental process of emerging ontological relations being the basis for such changes. 
It should be stated that another similarity between educational semiotics (Olteanu 2015: 28) and threshold concepts is that learning in terms of crossing threshold boundaries is a non-linear, recursive process (Cousin 2006). On top of this, Neve et al. (2016: 851) relate that threshold concepts will allow tutors to "learn to distinguish superficial understanding and mimicry from mastery, noticing where students are stuck, uncertain or confused".

From the semiotician's perspective, the term 'mastery' in the above statement could easily be described as semiosis. In the sense that mimesis ${ }^{6}$ is distinct from semiosis (Zlatev 2013), although mimesis can account for creative processes (Maran 2003), it is semiotics, as a sign-cognitive process that allows some form of paradigm shift to occur within the students (Zlatev, Andrén 2009). Hence, then, the difference between mastery and apprenticeship is the difference between a mimetic and a semiotic understanding of the educational process. In this sense the depth of the relationship (semiotics being more complex than mere mimicry) determines its usefulness as a carrier of meaning (Uexkülll 1934).

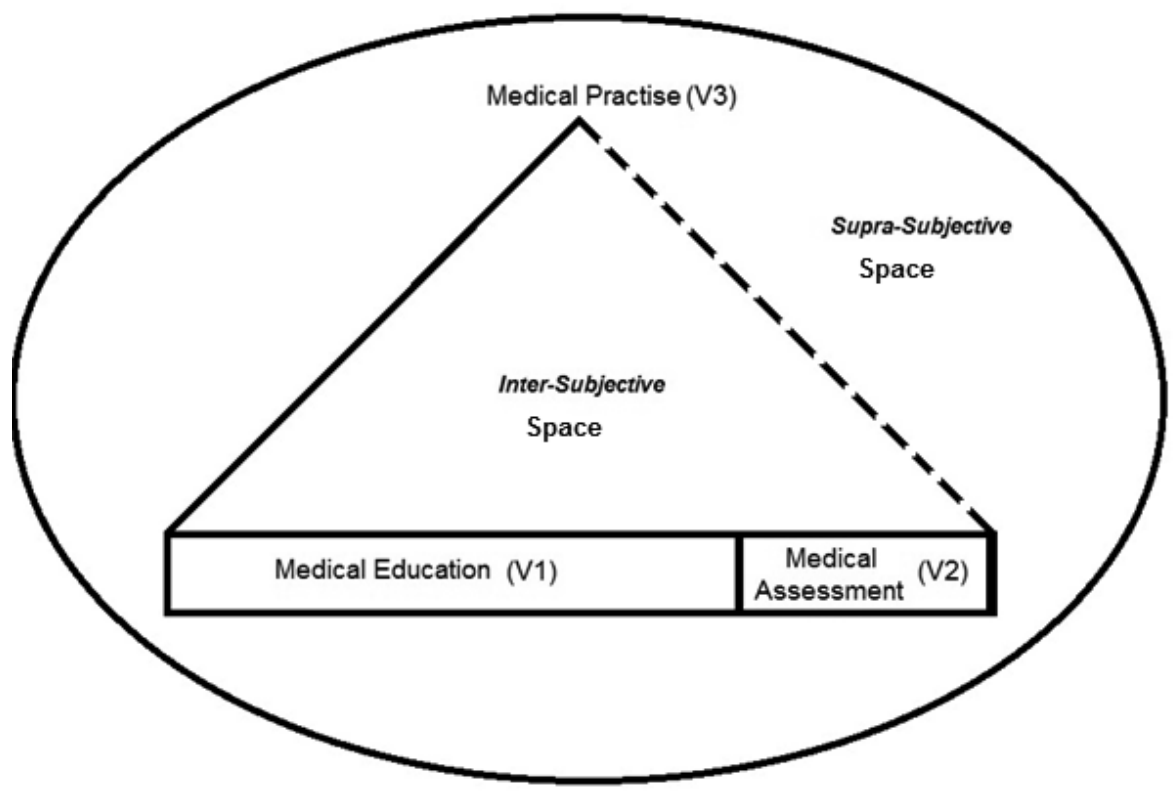

Figure 2. A suprasubjective interpretation of medical education and assessment.

6 Mimesis is the process through which visual patterns are matched to the real world, without reinterpretation. See Neiva 1999. 
Assessment drives learning, as George E Miller's adage states. Noting this, the medical educator is tasked with ensuring that the skills taught to students are useful in the real world of clinical practise. Fig. 2 illustrates the tensions that exist in terms of trying to find approaches to education and assessment that produce good doctors. Medical assessment is concerned that variables V1, medical education, and V2, assessment, are congruent, in that the assessment accurately captures the skills necessary to teaching students. However, there is a missing link, in that the assessments which medical students take do not adequately prepare them for the external realities of clinical practise (dashed line between V2 and V3). In other words, how the more sheltered (and more predetermined) world of education, can sufficiently represent the real world of clinical practice, in order to facilitate a seamless transition into it for aspiring medical professionals, remains a question. Considering Fig. 2, the ideal situation would be for variables V1, V2 and V3 all to be representative of one another. The challenge is that both medical education and medical practice require doctors to draw upon both objective and subjectivecontextual knowledge, but currently the majority of medical assessment does not. Even at this rudimentary level, one can see that using semiotics as a meta-theory to plan the delivery of educational services in relation to an intentional goal (i.e. becoming a good doctor) can benefit from Peirce's often cited and perhaps most straightforward definition of the sign:

A sign, or representamen, is something which stands to somebody for something in some respect or capacity. It addresses somebody, that is, creates in the mind of that person an equivalent sign or perhaps a more developed sign. That sign which it creates I call the interpretant of the first sign. (CP 2.228)

The quote clarifies the necessary structures that are required in medical education if we are to reform it, in order to meet the changing standards and requirements of our current age. Instead of a continuation of conservative institutional practices that tend towards re-enforcing existing patterns of behaviour, semiotics can account for the impingement of external actors (i.e. patient need, regulatory pressure etc.) that have a role to play in how we educate doctors of the future. Once more referring to Fig. 2, semiotics allows us to consider the appropriate relationships pertinent to how the intersubjective and suprasubjective interact.

The only way that this can happen is if medical assessment is brought in line with medical practice and education by incorporating more subjective assessments that test a student's ability to handle uncertainty, as indicated by John Dewey, and the pioneering work that is happening in Holland (Schuwirth, Van Der Vleuten 2011). I believe that this can be achieved by teaching students about threshold 
concepts, and integrating them into their assessments. For instance Randall (2017) has created reflective essay tasks for students that revolve around known threshold concepts.

From this perspective, reflective practice needs to be embedded both in medical education and assessment so that doctors are adequately trained to function meaningfully in the real world. This can only really be done from a suprasubjective interpretation of medical education. It also helps to counter the conception of medical humanities that encourage reflection as a merely decorative addendum. Rather, these examples help us assert that we can see how semiotics offers us the ability to structure and scaffold entire educational systems, making it a fundamental part of teaching doctors how to orientate themselves to the clinical environments that are increasingly profligate with new uncertainties and challenges. Although this paper concerns medical education, it has potential implications for other areas of professional education e.g., other clinical subjects, teachers, emergency services, etc.

Additionally, in this paper, I have sought to connect assessment and education as a united process rather than analysing the semiotics of education separately from assessment. I would contend that one area of future development in educational semiotics is to explore how assessment can be explained in a semiotic context, and its relationship to teaching and learning.

\section{Conclusion}

One might ask, why pursue this issue? Fundamentally, it would seem that current approaches to assessment within medical education are not sustainable in the long term. Following along the lines of Holmboe, it seems that ideological divisions are unhelpful in terms of designing medical education and assessment for the future. He remarked:

At the current time, too much of the educational discourse revolves around many "either-or" polarities or dichotomies, such as high-stakes tests versus work-based assessments, quantitative versus qualitative approaches to assessment, reductionism versus holism, process versus outcome, and so forth. Such either-or arguments are typically unhelpful - engaging in them often makes for a fun ideological exercise but in the end does not move the field forward or ultimately help patients. (Holmboe 2017: 3)

As such, I do not see medical humanities as an irreconcilable opposite to biological science, but instead as an area that needs to be integrated into a cohesive whole, 
with other subjects in a wider medical curriculum. The idea of suprasubjectivity as a structure or blueprint allows us to move towards this goal.

Both Holmboe (2017) and Kuhn (1962) noted that paradigm shifts can be messy, both for those looking to change to a new paradigm, but also for those wanting to remain within the current system. It would seem that the ontological shifts associated with threshold concepts embody this messiness, as they are characterized by traumatic or personally defining events, such as the first experience of a patient dying.

At the beginning of this paper, the question was asked what attributes and skills are required to make a good doctor. Having established that the quantification of assessment and outcome data can only take us so far in answering this interrogative, one can see why there is a desire for a paradigm shift in medical education, where one can both qualify and quantify the answers to this question. The qualification is best found in approaching medical education and assessment from a reflective, humanistic position, specifically by designing educational practices and assessments that situate medical students' learning within a suprasubjective context of sign relations. A practical example of this is the use of threshold concepts to determine the critical events that students pass through on their journey to becoming clinical professionals. By taking this approach I do not reject the validity of psychometrics, statistics or other quantitative approaches used in medical education, but rather acknowledge its epistemological limits, much as I must acknowledge the limits of "soft sciences" in medical education (Dacey, Wintrob 1973; Begun, Rieker 1980). Both have a role to play in mainstream medical education, and work should be undertaken to integrate both epistemological positons under a meta-level semiotic perspective, such as the scholastic realism of Charles Sanders Peirce and John Deely, that transcends stale dualistic (realistidealist) approaches by acknowledging that an objective, physical, biological reality exists, but within a system of suprasubjective sign relations.

\section{References}

Ansell, Julian S.; Boughton, Robert; Cullen, Tom; Hodges, Clarence; Nation, Earl; Peters, Paul; Scardino, Peter 1979. Lack of agreement between subjective ratings of instructors and objective testing of knowledge acquisition in a urological continuing medical education course. The Journal of Urology 122(6): 721-723.

Bachelard, Gaston 1968[1934]. Le nouvel esprit scientifique. (10th ed.) Paris: Les Presses universitaires de France. 
- 1940. La philosophie du non - Essai d'une philosophie du novel esprit scientifique. (7th ed.) Paris: Les Presses universitaires de France.

Bains, Paul 2014. The Primacy of Semiosis: An Ontology of Relations. (Toronto Studies in Semiotics and Communication.) Toronto: University of Toronto Press.

Barnard, Henry 1991. Bourdieu and ethnography: Reflexivity, politics and praxis. In: Harker, Richard; Mahar, Cheleen; Wilkes, Chris (eds.), An Introduction to the Work of Pierre Bourdieu: The Practice of Theory. London: Macmillian, 55-85.

Barry, Michael J.; Edgman-Levitan, Susan 2012. Shared decision making - the pinnacle of patient-centred care. New England Journal of Medicine 366(9): 780-781.

Beddhu, Srinivasan; Bruns, Frank J.; Saul, Melissa; Seddon, Patricia; Zeidel, Mark L. 2000. A simple comorbidity scale predicts clinical outcomes and costs in dialysis patients. The American Journal of Medicine 108(8): 609-613.

Begun, James W.; Rieker, Patricia P. 1980. Social science in medicine: The question of 'relevance'. Academic Medicine 55(3): 181-185.

Belling, Catherine 2010. Commentary: Sharper instruments: On defending the humanities in undergraduate medical education. Academic Medicine 85(6): 938-940.

Biesta, Gert 1994. Pragmatism as a pedagogy of communicative action. Studies in Philosophy and Education 13(3): 273-290.

- 2010. "This is my truth, tell me yours". Deconstructive pragmatism as a philosophy for education. Educational Philosophy and Theory 42(7): 710-727.

Biesta, Gert; Burbules, Nicholas C. 2003. Pragmatism and Educational Research. Boston: Rowman \& Littlefield Publishers.

Bleakley, Alan. 2014. Patient-Centred Medicine in Transition: The Heart of the Matter, Advances in Medical Education. London: Springer.

Bloomfield, Leah; Harris, Peter; Hughes, Chris 2003. What do students want? The types of learning activities preferred by final year medical students. Medical Education 37(2): 110118.

Bourdieu, Pierre 1988. Vive la Crise!: For heterodoxy in social science. Theory and Society 17(5): 773-787.

- 1990. In Other Words: Essays Toward a Reflexive Sociology. (Adamson, Matthew, trans.) Malden: Polity Press.

- 2004. Science of Science and Reflexivity. (Nice, Richard, trans.) Cambridge: Polity Press.

Bourdieu, Pierre; Wacquant, Loïc J. D. 1992. An Invitation to Reflexive Sociology. Chicago: University of Chicago Press.

Camp, Gwendie 1996. Problem-based learning: A paradigm shift or a passing fad? Medical Education Online 1(1): 4282-4288.

Campbell, Cary 2016. Indexical ways of knowing: An inquiry into the indexical sign and how to educate for novelty. Philosophical Inquiry in Education 24(1): 15-36.

Cardoso, Hélio Rebello 2016. Peirce and Foucault on time and history: The tasks of (dis)continuity. History and Theory 55(1): 25-38.

Cobley, Paul. 2017. Integrationism, anti-humanism and the suprasubjective. In: Pablé, Adrian (ed.), Critical Humanist Perspectives: The Integrational Turn in Philosophy of Language and Communication. Oxford: Routledge, 267-284.

Collett, Tracey; Neve, Hillary; Stephen, Nicole 2017. Using audio diaries to identify threshold concepts in "softer" disciplines: A focus on medical education. Practice and Evidence of the Scholarship of Teaching and Learning in Higher Education 12(2): 99-117. 
Conti, Richard C. 2005. What makes a doctor good? Clinical Cardiology 28: 496-498.

Cook, David A.; Brydges, Ryan; Ginsburg, Shiphra; Hatala, Rose 2015. A contemporary approach to validity arguments: A practical guide to Kane's framework. Medical Education 49(6): 560-575.

Cook, David A.; Kuper, Ayelet; Hatala, Rose; Ginsburg, Shiphra 2016. When assessment data are words: Validity evidence for qualitative educational assessments. Academic Medicine 91(10): 1359-1369.

Cousin, Glynis 2006. An introduction to threshold concepts. Planet 17: 4-5.

Cox, Helen; Hargreaves, Sally; Ismailov, Gabit 2003. Normative role for medical humanities. The Lancet 362: 1859.

CP = Peirce, Charles Sanders 1992. The Collected Papers of Charles Sanders Peirce. Vol. 5. In: Past Masters. Charlottesville: InteLex Corporation.

D'Agnese, Vasco 2017. The essential uncertainty of thinking: Education and subject in John Dewey. Journal of Philosophy of Education 51(1): 73-88.

Dacey, M. Lynn; Wintrob, Ronald M. 1973. Human behavior: The teaching of social and behavioral sciences in medical schools. Social Science \& Medicine (1967) 7(12): 943-957.

Deely, John 2000. The Green Book: The Impact of Semiotics on Philosophy. Helsinki: University of Helsinki.

- 2009. Why intersubjectivity is not enough. In: Deely, John (ed.), Purely Objective Reality. Berlin: Mouton de Gruyter, 143-164.

- 2014. Subjectivity, suprasubjectivity, and semiosis. Chinese Semiotic Studies 10(14): 593-604.

- 2015. Ethics and the semiosis-semiotics distinction. Zeitschrift für Semiotik 37(3-4): 13-30.

Deely, John; Cobley, Paul 2010. Realism for the 21st Century: A John Deely Reader. Chicago: University of Chicago Press.

Deely, John; Semetsky, Inna 2017. Semiotics, edusemiotics and the culture of education. Educational Philosophy and Theory 49(3): 207-219.

Deleuze, Gilles 1990. Logic of Sense. (Lester, Mark; Stivale, Charles, trans.; Boundas, Constantin V., ed.) New York: Columbia University Press.

DesAutels, Peggy 1996. Gestalt shifts in moral perception. In: May, Larry; Friedman, Marilyn; Clark, Andy (eds.), Mind and Morals: Essays on Cognitive Science and Ethics. Boston: MIT Press, 129-143.

Dewey, John 1910. How We Think. Boston: D. C. Heath \& Co.

- 1917. The need for a recovery of philosophy. In: Dewey, John; Moore, Addison Webster; Brown, Harold Chapman; Mead, George Herbert; Bode, Boyd Henry; Stuart, Henry Waldgrave; Tufts, James Hayden; Kallen, Horace M. (eds.), Creative Intelligence: Essays in the Pragmatic Attitude. New York: Henry Holt and Co., 3-69.

Fones, Calvin S.; Kua, Ee Heok; Goh, Lee Gan 1998. "What makes a good doctor?” - views of the medical profession and the public in setting priorities for medical education. Singapore Medical Journal 39(12): 537-542.

French, Steven 2011. Shifting to structures in physics and biology: A prophylactic for promiscuous realism. Studies in History and Philosophy of Science Part C: Studies in History and Philosophy of Biological and Biomedical Sciences 42(2): 164-173.

Frenk, Julio; Chen, Lincoln; Bhutta, Zulfiqar A.; Cohen, Jordan; Crisp, Nigel; Evans, Timothy; Fineberg, Harvey; Garcia, Patricia; Ke, Yang; Kelley, Patrick; Kistnasamy, Barry; Meleis, Afaf; Naylor, David; Pablos-Mendez, Ariel; Reddy, Srinath; Scrimshaw, Susan; Sepulveda, Jaime; Serwadda, David; Zurayk, Huda 2010. Health professionals for a new century: Transforming 
education to strengthen health systems in an interdependent world. The Lancet 376(9756): 1923-1958.

Gallagher, Anthony G.; Ritter, E. Matt; Champion, Howard; Higgins, Gerald; Fried, Marvin P.; Moses, Gerald; Smith, C. Daniel; Satava, Richard M. 2005. Virtual reality simulation for the operating room: Proficiency-based training as a paradigm shift in surgical skills training. Annals of Surgery 241(2): 364-372.

Garrison, Jim 1994. Realism, Deweyan pragmatism, and educational research. Educational Researcher 23(1):5-14.

- 1997. Dewey and Eros: Wisdom and Desire in the Art of Teaching. (Advances in Contemprorary Educational Thought Series 19.) New York, London: Teachers College Press.

- 1998. Foucault, Dewey and self-creation. Educational Philosophy and Theory 30(2): 111-134.

- 2003. Dewey, Derrida, and 'the double bind'. Educational Philosophy and Theory 35(3): 349-362.

Garrison, James W.; Shargel, Emanuel I. 1988. Dewey and Husserl: A surprising convergence of themes. Educational Theory 38(2): 239-247.

Ginsburg, Shiphra; Regehr, Glenn; Lingard, Lorelei; Eva, Kevin W. 2015. Reading between the lines: Faculty interpretations of narrative evaluation comments. Medical Education 49(3): 296-306.

Gordon, Jill 2005. Medical humanities: To cure sometimes, to relieve often, to comfort always. Med J Aust 182(1): 5-8.

Guattari, Felix 1995. Chaosmosis: An Ethicoaesthetic Paradigm. (Prefaris, Julian; Bains, Paul, trans.) Bloomington: Indiana University Press.

Hanson, Janice Lynn; Rosenberg, Adam A.; Lane, J. Lindsey 2013. Narrative descriptions should replace grades and numerical ratings for clinical performance in medical education in the United States. Frontiers in Psychology 4: 668.

Holmboe, Eric S. 2017. Competency-based medical education and the ghost of Kuhn: Reflections on the messy and meaningful work of transformation. Academic Medicine Publish Ahead of Print.

Holmboe, Eric S.; Sherbino, Jonathan; Englander, Robert; Snell, Linda; Frank, Jason R. 2017. A call to action: The controversy of and rationale for competency-based medical education. Medical Teacher 39(6): 574-581.

Howley, Lisa D. 2004. Performance assessment in medical education. Evaluation \& the Health Professions 27(3): 285-303.

Hurwitz, Brian; Vass, Alex 2002. What's a good doctor, and how can you make one? By marrying the applied scientist to the medical humanist. BMJ 325(7366): 667-668.

Huxham, G. J.; Lipton, A., Hamilton, D.; Chant, D. 1989. What 'makes' a good doctor? Medical Education 23(1): 3-13.

Institute of Medicine 2001. Crossing the quality chasm: A new health system for the 21st century. Washington: National Academy Press.

Iobst, William F.; Sherbino, Jonathan; Ten Cate, Olle; Richardson, Denyse L.; Dath, Deepak; Swing, Susan R.; Harris, Peter; Mungroo, Rani; Holmboe, Eric S.; Frank, Jason R. 2010. Competency-based medical education in postgraduate medical education. Medical Teacher 32(8): 651-656.

Jaipal, Kamini 2010. Meaning making through multiple modalities in a biology classroom: A multimodal semiotics discourse analysis. Science Education 94(1): 48-72. 
Jauernig, Anja 2010. Disentangling Leibniz's views on relations and extrinsic denominations. Journal of the History of Philosophy 48(2): 171-205.

Keane, Webb 2003. Semiotics and the social analysis of material things. Language \& Communication 23(3): 409-425.

Kuhn, Thomas S. 1962. The Structure of Scientific Revolutions. Chicago: University of Chicago Press.

Kull, Kalevi. 2017. Umberto Eco and John Deely: What they shared. Sign Systems Studies 45(12): 194-204.

Lachman, Sheldon J. 1997. Learning is a process: Toward an improved definition of learning. The Journal of Psychology 131(5): 477-480.

Leahy, Marjorie; Cullen, Walter; Bury, Gerard 2003. "What makes a good doctor?” A cross sectional survey of public opinion. Irish Medical Journal 96(2): 38-41.

Lemke, Jay L. 1987. Social semiotics and science education. The American Journal of Semiotics 5(2): 217-232.

Leone, Massimo. 2017. "Help! Is there a semiotician on the plane?" The American Journal of Semiotics 33(1-2): 113-130.

Maran, Timo 2003. Mimesis as a phenomenon of semiotic communication. Sign Systems Studies 31(1): 191-215.

Marx, Karl; Hegel, Georg Wilhelm Friedrich 1956[1845]. The Holy Family or Critique of Critical Criticism: Against Bruno Bauer and Company. Moscow,: Foreign Language Publishing House.

McManus, I. C. 1995. Humanity and the medical humanities. The Lancet 346(8983): 1143-1145.

Mesny, Ann 2002. A view on Bourdieu's legacy: Sens pratique v. hysteresis. The Canadian Journal of Sociology /Cahiers canadiens de sociologie 27(1): 59-67.

Meyer, Jan H. F.; Land, Ray 2003. Threshold concepts and troublesome knowledge: Linkages to ways of thinking and practising. In: Improving Student Learning - Theory and Practice Ten Years On. (Rust, Chris, ed.) Oxford: Oxford Centre for Staff and Learning Development (OCSLD), 412-424.

- 2005. Threshold concepts and troublesome knowledge (2): Epistemological considerations and a conceptual framework for teaching and learning. Higher Education 49(3): 373-388.

- 2006. Overcoming Barriers to Student Understanding: Threshold Concepts and Troublesome Knowledge. Oxford: Routledge.

Morgan, Candia 2006. What does social semiotics have to offer mathematics education research? Educational Studies in Mathematics 61(1): 219-245.

Neiva, Eduardo 1999. Redefining the image: Mimesis, convention, and semiotics. Communication Theory 9(1): 75-91.

Neve, Hilary; Wearn, Andy; Collett, Tracey 2016. What are threshold concepts and how can they inform medical education? Medical Teacher 38(8): 850-853.

O’Neil, Luke 2010. What makes a good doctor? Medicus 50(11): 31.

Olteanu, Alin 2015. Philosophy of Education in the Semiotics of Charles Peirce: A Cosmology of Learning and Loving. Oxford: Peter Lang.

- 2016. The implications for education of Peirce's agapist principle. Semiotica 212: 59-79.

- 2017. Reading history: Education, semiotics, and edusemiotics. In: Semetsky, Inna (ed.), Edusemiotics - A Handbook. Singapore: Springer Singapore, 193-205.

Patel, Gopi. 2007. What makes a good doctor? British Journal of General Practice 57(536): 244-245. 
Pauli, Hannes G; White, Kerr L.; McWhinney, Ian R. 2000a. Medical education, research, and scientific thinking in the 21st century (Part one of three). Education for Health 13(1): 15-25.

- 2000b. Medical education, research, and scientific thinking in the 21st century (Part two of three). Education for Health 13(2): 165-172.

- 2000c. Medical education, research, and scientific thinking in the 21st century (Part three of three). Education for Health 13(2): 173-186.

Peirce, Charles Sanders 1997[1903]. Pragmatism as a Principle and Method of Right Thinking: The 1903 Harvard Lectures on Pragmatism. Buffalo: State University of New York Press.

Pellegrino, Edmund D. 1999. The commodification of medical and health care: The moral consequences of a paradigm shift from a professional to a market ethic. Journal of Medicine and Philosophy 24(3): 243-266.

Perkins, David 2006. Constructivism and troublesome knowledge. In: Meyer, Jan H. F.; Land, Ray (eds.), Overcoming Barriers to Student Understanding: Threshold Concepts and Troublesome Knowledge. Oxford: Routledge, 33-47.

Pikkarainen, Eetu. 2011. The semiotics of education: A new vision in an old landscape. Educational Philosophy and Theory 43(10): 1135-1144.

Rabinow, Hubert L.; Dreyfus, Paul 1982. Michel Foucault: Beyond Structuralism and Hermeneutics. Chicago: The University of Chicago Press.

Randall, Virginia 2017. Ontological changes in the journey to medicine: Characterising threshold concepts from reflective essays. Threshold Concepts in Medical Education, C521 PSQ University of Plymouth 01/09/2017.

Regehr, Glenn; Ginsburg, Shiphra; Herold, Jodi; Hatala, Rose; Eva, Kevin; Oulanova, Olga 2012. Using "standardized narratives" to explore new ways to represent faculty opinions of resident performance. Academic Medicine 87(4): 419-427.

Scalese, Ross J.; Obeso, Vivian T.; Issenberg, S. Barry 2008. Simulation technology for skills training and competency assessment in medical education. Journal of General Internal Medicine 23(1): 46-49.

Schuwirth, Lambert W. T.; Van Der Vleuten, Cees 2011. Programmatic assessment: From assessment of learning to assessment for learning. Medical Teacher 33(6): 478-485.

Semetsky, Inna 2014. Taking the edusemiotic turn: A body mind approach to education. Journal of Philosophy of Education 48(3): 490-506.

Shank, Garry 1995. Semiotics and qualitative research in education: The third crossroad. The Qualitative Report 2(3): 1-11.

Sloan, David A.; Donnelly, Michael B.; Schwartz, Richard W.; Felts, Janet L.; Blue, Amy V.; Strodel, William E. 1996. The use of the Objective Structured Clinical Examination (OSCE) for evaluation and instruction in graduate medical education. Journal of Surgical Research 63(1): 225-230.

Sonesson, Göran 2018. Meaning redefined: Reflections on the scholastic heritage conveyed by John Deely to contemporary semiotics. The American Journal of Semiotics 34(1-2): 65-86.

Stables, Andrew; Semetsky, Inna 2016. Edusemiotics: Semiotic Philosophy as Educational Foundation. (New Directions in the Philosophy of Education.) Oxford: Routledge.

Strand, Torill 2013. Peirce's Rhetorical Turn: Conceptualizing education as semiosis. Educational Philosophy and Theory 45(7): 789-803.

Sullivan, Mark 2003. The new subjective medicine: Taking the patient's point of view on health care and health. Social Science \& Medicine 56(7): 1595-1604. 
Uexküll, Jakob von 1934. A Foray into the Worlds of Animals and Humans with a Theory of Meaning. Minneapolis: University of Minnesota Press.

Wearn, Andy; O'Callaghan, Anne; Barrow, Mark 2016. Becoming a different doctor: Identifying threshold concepts when doctors in training spend six months with a hospital palliative care team. In: Land, Ray; Meyer, Jan H. F.; Flanagan, Michael T. (eds.), Threshold Concepts in Practice. Rotterdam, Boston, Taipei: Sense Publishers, 223-238.

Wilshire, Bruce 1993. Body-mind and subconsciousness: Tragedy in Dewey's life and work. In: Stuhr, John J. (ed.), Philosophy and the Reconstruction of Culture. Albany: State University of New York Press, 257-272.

Zlatev, Jordan 2013. The Mimesis Hierarchy of semiotic development: Five stages of intersubjectivity in children. The Public Journal of Semiotics 4(2): 47-70.

Zlatev, Jordan; Andrén, Mats 2009. Stages and transitions in children's semiotic development. In: Zlatev, Jordan; Andrén, Mats; Lundmark, Carita; Johansson Falck, Marlene (eds.), Studies in Language and Cognition. Newcastle: Cambridge Scholars Publishing, 380-401.

\section{Может ли семиотика стимулировать изменения парадигмы в медицинском образовании?}

Статья намеревается объяснить, каким образом семиотика образования как дисциплина может использоваться в реформе медицинского образования, которая стремится объединять более качественные, этические и профессиональные аспекты медицины в учебные планы и развивать способы оценить их. Полагается, что метод для стимулирования изменения парадигмы мог бы быть найден в пирсовской идее супрасубъективности. Это семиотическое понятие внедрено в схоластической философии Джона Пуансо, но было вновь введено в современную семиотику в работах Пирса, Джона Дили и Алин Олтеану. Как преподаватель медицины и семиотик я имею доступ и к информации об изменениях парадигмы в медицинском образовании и к понятию супрасубъективности в современной образовательной семиотической литературе. Считаю, что супрасубъективный подход к медицинскому образованию и оцениванию мог бы быть крайне полезным. В медицинском образовании существенным недостатком является напряжение, возникающее от стремления научить будущих врачей пониманию равновесия между биологической научностью и этическими суждениями, вытекающими из конкретной ситуации. Именно схоластическая философия Джона Пуансо может быть решением, в котором нуждается медицина для преодоления этой дихотомии.

\section{Kas semiootikat saab kasutada, et käivitada paradigmamuutusi meditsiinihariduses?}

Artikli eesmärgiks on selgitada, kuidas haridussemiootikat kui distsipliini saab kasutada meditsiinihariduse ja hindamise reformis. See on vastus käimasolevale paradigmanihkele meditsiinihariduses ning hindamises, milles püütakse lõimida meditsiini kvalitatiivseid, eetilisi ja professionaalseid aspekte õppekavadesse ning töötada välja viise nende hindamiseks. Artiklis osutatakse, et ühe meetodi selle paradigmamuutuse käivitamiseks võib leida Peirce'i 


\section{6}

John Tredinnick-Rowe

suprasubjektiivsuse ideest. Selle semiootilise mõiste juured ulatuvad João Poinsot' skolastilisse filosoofiasse, ent see on semiootikas taas kasutusele võetud John Deely, Alin Olteanu ja varem Charles Sanders Peirce’i teostes. Lähenen sellele ülesandele nii meditsiiniõppejõu kui ka semiootikuna. Artiklis kirjeldan meditsiiniharidust, paradigmanihkeid ja suprasubjektiivsuse mõistet puudutavat taustteavet seotuna tänapäevase haridussemiootilise kirjandusega. Toon näiteid selle kohta, milline võiks välja näha suprasubjektiivne lähenemine meditsiiniharidusele ja hindamisele. Teen seda, võrdustades semiootilise läve ning suprasubjektiivsuse mõisteid ja näidates sarnasusi nende vaatepunktide vahel. Meditsiinihariduses on oluliseks puuduseks pinged, mis tekivad püüetest õpetada arstitudengitele bioloogilise teaduslikkuse ning situatsioonist lähtuvate eetiliste otsustuste vahelist tasakaalu. Vaimust sõltuva ja vaimust sõltumatu olemise ületamises võib Poinsot' skolastiline filosoofia olla täpselt see lahendus, mida meditsiin vajab sellest dihhotoomiast üle saamiseks. 